\title{
Gene Activations of CYP2B1 and CYP3A1 by Dihydropyridine Calcium Channel Antagonists in the Rat Liver: the Structure-Activity Relationship
}

\author{
Yoshihiro Konno and Masakuni DegawA* \\ Department of Molecular Toxicology and COE Program in the 21st Century, School of Pharmaceutical Sciences, \\ University of Shizuoka; Shizuoka 422-8526, Japan. ～Received January 13, 2004; accepted February 18, 2004
}

\begin{abstract}
We investigated the gene activations of CYP2B1 and CYP3A1 by 1,4-dihydropyridine calcium channel antagonists, including nifedipine (Nif), nisoldipine (Nis), nitrendipine (Nit), nimodipine (Nim), and nicardipine (Nic), in the rat liver and their structure-activity relationships. All calcium channel antagonists used have nitrophenyl substituents at the 4-position of the dihydropyridine ring and their nitro group was located at $o$ - or $m$-position. The $m$-nitro derivatives Nic, Nim, and Nit showed much higher capacities for activating CYP3A1 than the $o$-nitro derivatives Nif and Nis. On the other hand, in the activation of $C Y P 2 B 1$, the length of the side chain at the 3-position of the dihydropyridine ring was correlated with the activating capacity of each chemical, and Nif and Nit, with a shorter side chain than the other calcium channel antagonists examined, had potent capacities. The present findings suggest that the ability of dihydropyridine calcium channel antagonists to activate the $C Y P 2 B 1$ and $C Y P 3 A 1$ are mainly dependent on the length of the side chain at the 3-position of the dihydropyridine ring and the position of the nitro group in the nitrophenyl substituent, respectively.
\end{abstract}

Key words calcium channel antagonist; CYP2B1; CYP3A1; P450 induction; structure-activity relationship; rat liver

Calcium channel antagonists are widely used for the treatment of hypertension. However, it is known that calcium channel antagonists sometimes give rise to clinical drugdrug interactions. ${ }^{1-4)}$ As one possible explanation for such drug-drug interactions, the inhibition of cytochrome P450 (P450) enzymes, especially CYP3A subfamily enzymes, by calcium channel antagonists has been proposed. ${ }^{5,6)}$ On the other hand, several calcium channel antagonists have also been reported to induce CYP2B and CYP3A subfamily enzymes in the rat liver ${ }^{7-9)}$ and human primary cultured hepatocytes. ${ }^{10)}$ Therefore further studies on not only the inhibition but also the induction of P450 enzymes by calcium channel antagonists are necessary to understand drug-drug interactions.

Calcium channel antagonists, including nicardipine (Nic), nifedipine (Nif), verapamil, and diltiazem, are able to induce both CYP2B and CYP3A subfamily enzymes with different selectivity. ${ }^{7-9)}$ Nic and Nif are representative inducers of CYP3A1 and CYP2B1, respectively, among the calcium channel antagonists in the rat liver. ${ }^{8,9)}$ Although the difference in selectivity between Nic and Nif is assumed to result from the difference in their chemical structure, no study of the structure-activity relationship in the induction of P450 enzymes has been performed.

In the present study using dihydropyridine calcium channel antagonists such as Nif, nitrendipine (Nit), nisoldipine (Nis), nimodipine (Nim), and Nic, we examined structureactivity relationships in the activation of $C Y P 2 B 1$ and CYP3A1 in the rat liver and suggest that the length of the side chain at the 3-position of the dihydropyridine ring and the position of the nitro group in the nitrophenyl substituent are important factors for determining the capacity of a dihydropyridine calcium channel antagonist to activate $C Y P 2 B 1$ and CYP3A1.

\section{MATERIALS AND METHODS}

Chemicals Nic, Nif, Nim, Nit and Nis were purchased from Wako Pure Chemicals (Osaka, Japan), and their chemi- cal structures are shown in Fig. 1. These chemicals were of the highest grade available.

Animals and Treatment Male F344 rats (6 weeks of age) were purchased from Japan SLC Animal (Hamamatsu, Japan), kept in plastic cages in an air-conditioned room, given an MF diet (Oriental Yeast, Tokyo, Japan) and water $\mathrm{ad}$ libitum, and used at 7 weeks of age. Rats were treated with one of calcium channel antagonists $(200 \mu \mathrm{mol} / \mathrm{kg}$, p.o. $)$ dissolved in corn oil. ${ }^{8)}$ Control rats were treated with vehicle alone.

RT-PCR Analysis Total hepatic RNA was prepared by the method as described previously ${ }^{8}$ and used for the determination of expression levels of CYP2B1 and CYP3A1. In addition, the gene expression level of glyceraldehyde-3-phosphate-dehydrogenase (GAPDH) was measured as an internal control.

Complementary DNA (cDNA) was prepared from total

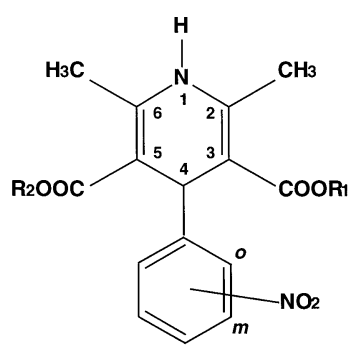

\begin{tabular}{lcll}
\hline \hline Chemical & $\begin{array}{l}\text { Position of } \\
\text { nitro group }\end{array}$ & \multicolumn{1}{c}{$\mathrm{R} 1$} & $\mathrm{R} 2$ \\
\hline Nifedipine (Nif) & ortho & $\mathrm{CH}_{3}$ & $\mathrm{CH}_{3}$ \\
Nisoldipine (Nis) & ortho & $\mathrm{CH}_{2} \mathrm{CH}\left(\mathrm{CH}_{3}\right)_{2}$ & $\mathrm{CH}_{3}$ \\
Nitrendipine (Nit) & meta & $\mathrm{CH}_{2} \mathrm{CH}_{3}$ & $\mathrm{CH}_{3}$ \\
Nimodipine (Nim) & meta & $\mathrm{CH}_{2} \mathrm{CH}_{2} \mathrm{OCH}_{3}$ & $\mathrm{CH}\left(\mathrm{CH}_{3}\right)_{2}$ \\
Nicardipine (Nic) & meta & $\mathrm{CH}_{2} \mathrm{CH}_{2} \mathrm{~N}\left(\mathrm{CH}_{3}\right) \mathrm{CH}_{2} \mathrm{C}_{6} \mathrm{H}_{5}$ & $\mathrm{CH}_{3}$ \\
\hline
\end{tabular}

Fig. 1. Chemical Structures of the Dihydropyridine Calcium Channel Antagonists Used in the Present Experiment 
Table 1. PCR Conditions Used in the Present Experiments

\begin{tabular}{|c|c|c|c|c|c|c|c|}
\hline \multirow{2}{*}{ Target } & & \multirow{2}{*}{ Primer sets } & \multicolumn{3}{|c|}{ Reaction conditions } & \multirow{2}{*}{$\begin{array}{l}\text { Product } \\
\text { size (bp) }\end{array}$} & \multirow{2}{*}{ Ref } \\
\hline & & & Denaturation & Annealing & Elongation & & \\
\hline$C Y P 2 B 1$ & $\begin{array}{l}\text { Forward } \\
\text { Reverse }\end{array}$ & $\begin{array}{l}\text { 5'-GCTCAAGTACCCCCATGTCG-3' } \\
\text { 5'-ATCAGTGTATGGCATTTTACTGCGG-3' }\end{array}$ & $93^{\circ} \mathrm{C}, 1 \mathrm{~min}$ & $54^{\circ} \mathrm{C}, 1.5 \mathrm{~min}$ & $72^{\circ} \mathrm{C}, 1 \mathrm{~min}$ & 109 & 11) \\
\hline CYP3A1 & $\begin{array}{l}\text { Forward } \\
\text { Reverse }\end{array}$ & $\begin{array}{l}\text { 5'-GATGTTGAAATCAATGGTGTGT-3' } \\
\text { 5'-TTCAGAGGTATCTGTGTTTCC-3' }\end{array}$ & $95^{\circ} \mathrm{C}, 1 \mathrm{~min}$ & $60^{\circ} \mathrm{C}, 1 \mathrm{~min}$ & $72^{\circ} \mathrm{C}, 2 \mathrm{~min}$ & 289 & 12) \\
\hline$G A P D H$ & $\begin{array}{l}\text { Forward } \\
\text { Reverse }\end{array}$ & $\begin{array}{l}\text { 5'-TTCAACGGCACAGTCAAGG-3' } \\
5^{\prime} \text {-CATGGACTGTGGTCATGAG-3' }\end{array}$ & $95^{\circ} \mathrm{C}, 1 \mathrm{~min}$ & $60^{\circ} \mathrm{C}, 1 \mathrm{~min}$ & $72^{\circ} \mathrm{C}, 2 \mathrm{~min}$ & 373 & 13) \\
\hline
\end{tabular}

RNA by the method as described previously. ${ }^{8)}$ In brief, a portion $(4 \mu \mathrm{g})$ of total RNA was converted to cDNA using a poly $\mathrm{d}(\mathrm{N})_{6}$ primer (Amersham Pharmacia Biotech, Inc., Piscataway, NJ, U.S.A.) and Moloney murine leukemia virus reverse transcriptase (Gibco BRL, Tokyo, Japan) in an RT reaction mixture $(20 \mu \mathrm{l})$.

PCR was performed in a total reaction mixture $(25 \mu \mathrm{l})$ containing $0.8 \mu \mathrm{l}$ of the RT reaction mixture, $0.5 \mu \mathrm{l}$ of the corresponding primer sets (Table 1), and AmpliTaq Gold DNA polymerase (Applied Biosystems, Branchbarg, NJ, U.S.A.). The amount of product generated by each PCR increased linearly in a PCR cycle-dependent manner over the following ranges: $22-29$ cycles for $C Y P 2 B 1 ; 21-25$ cycles for $C Y P 3 A 1$; and $20-30$ cycles for $G A P D H$. PCR products were separated by electrophoresis on a $2 \%$ agarose gel. The amount of the separated PCR-product was determined densitometrically with a computer using Kodak 1D Image Analysis Software (Machintosh 1D version 2.02) after visualization with ethidium bromide staining under UV light.

Statistical Analysis Significant differences from the corresponding controls were assessed using Student's $t$-test.

\section{RESULTS}

The effects of calcium channel antagonists on the expression of $C Y P 2 B 1$ and $C Y P 3 A 1$ in the rat liver were examined with RT-PCR with the corresponding primer sets. We have previously reported that in the male rat liver expression levels of $C Y P 2 B 1$ and $C Y P 3 A 1$ were linearly increased in a time-dependent manner, at least up to $6 \mathrm{~h}$ after treatment with Nic or Nif, representative inducers of CYP3A1 and CYP2B1, respectively, among calcium channel antagonists, and in a dose-dependent manner up to $200 \mu \mathrm{mol} / \mathrm{kg}$ of Nic or Nif. ${ }^{8,9)}$ Therefore in the present experiments, $200 \mu \mathrm{mol} / \mathrm{kg}$ was used as the dose of each calcium channel antagonist, and expression levels of $C Y P 2 B 1$ and $C Y P 3 A 1$ were examined $6 \mathrm{~h}$ after treatment of male rats with each chemical.

Representative expression patterns of P450 genes after treatment with the dihydropyridine calcium channel antagonists are shown in Fig. 2. In addition, no significant change in the expression level of $G A P D H$, an internal standard, was observed. All calcium channel antagonists examined activated $C Y P 2 B 1$ in the following order: Nif, Nit $>$ Nis, Nim $>$ Nic (Fig. 3). Nif and Nit increased the expression level of $C Y P 2 B 1$ to about 10-fold the control level, and Nis and Nim to about 8-fold the control level. Treatment with Nic increased the expression to about 4-fold the control level.

On the other hand, in the activation of $C Y P 3 A 1$, the calcium channel antagonists were in the following order: Nic,

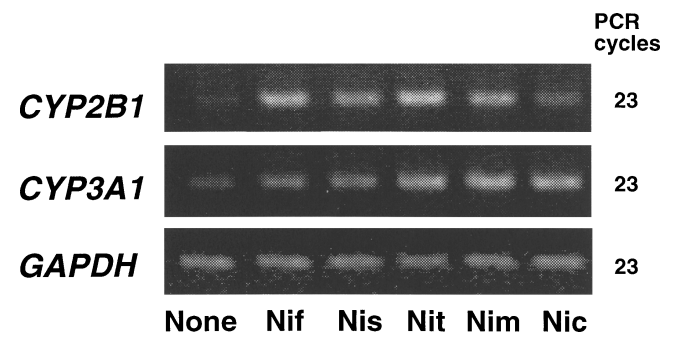

Fig. 2. Representative Expression Patterns of Hepatic CYP2B1, CYP3A1, and $G A P D H$ after Treatments of Rats with Dihydropyridine Calcium Channel Antagonists

Rats were treated with corn oil (control) or a calcium channel antagonist (Nif, Nis, Nit, Nim or Nic) and killed $6 \mathrm{~h}$ later. Total hepatic RNAs were extracted from each experimental group of rats and used for RT-PCR analyses, as described in Materials and Methods.

Nim, Nit $>>$ Nis, Nif (Fig. 3). The ability of Nic, Nim, and Nit to activate CYP3A1 was almost the same, and they led to increase the gene expression level to about 4-fold the control level. On the other hand, Nif and Nis had little ability to activate this gene.

\section{DISCUSSION}

In the present study, we demonstrated that dihydropyridine calcium channel antagonists such as Nif, Nis, Nit, Nim, and Nic activate $C Y P 2 B 1$ and/or $C Y P 3 A 1$ with different selectivity. Nif and Nic were demonstrated to be the most selective inducers of $C Y P 2 B 1$ and $C Y P 3 A 1$, respectively, among the dihyropyridine calcium channel antagonists examined, although we have recently reported that Nif and Nic are phenobarbital- and dexamethasone-type inducers of hepatic P450 enzymes, respectively, with regard to the selectivity in inducing the P450 enzymes. ${ }^{8,9)}$ The difference among dihydropyridine calcium channel antagonists in the selective activation of the P450 genes seems to result from differences in the position of the nitro group in the nitrophenyl substituent and the length of the side chain at the 3-position of the dihydropyridine ring. In particular, the position of the nitro group in a nitrophenyl substituent was suggested to be an important factor in determining the ability of a dihydropyridine calcium channel antagonist to activate $C Y P 3 A 1$, because the activity of Nic, Nit, and Nim, with a nitro group at the $m$-position, was selective. On the other hand, the ability of dihyropyridine calcium channel antagonists to activate $C Y P 2 B 1$ appears to be correlated with the length of the side chain at the 3-position of the dihydropyridine ring, because Nif and Nit with shorter side chains had greater ability.

As one mechanism for the activation of $C Y P 2 B 1$ and 

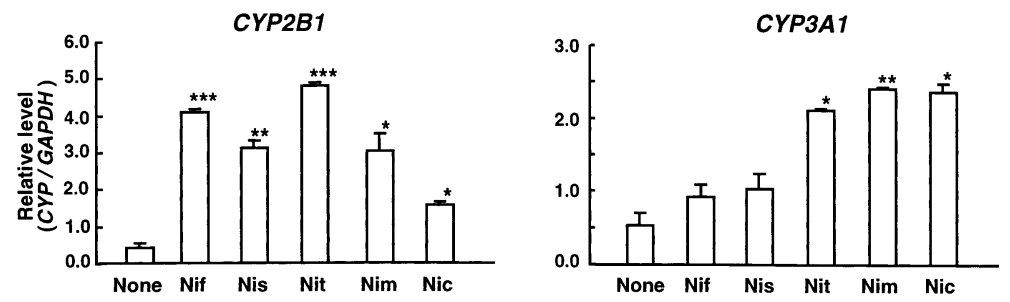

Fig. 3. Activation of $C Y P 2 B 1$ and $C Y P 3 A 1$ by Dihydropyridine Calcium Channel Antagonists

Rats were treated with corn oil (control) or a calcium channel antagonist (Nif, Nis, Nit, Nim, or Nic; $200 \mu$ mol/kg) and killed $6 \mathrm{~h}$ later. Total hepatic RNAs were extracted from three individual rats in each experimental group and used for the RT-PCR analysis, as described in Materials and Methods. The data represent the means, and the bars show standard deviations of the means. Significant differences from the corresponding controls: $* p<0.05, * * p<0.01, * * * p<0.001$.

CYP3A1 by dihydropyridine calcium channel antagonists, the pregnane $\mathrm{X}$ receptor (PXR)-mediated pathway should be considered, because dihydropyridine calcium channel antagonists, including Nic and Nif, were found to act as ligands for PXR, but not for constitutive androstane receptor (CAR), and assumed to activate the genes of the CYP2B and CYP3A subfamily enzymes through a PXR-dependent pathway. ${ }^{10)}$ However, differences in the selectivity of the activation of $C Y P 2 B 1$ and $C Y P 3 A 1$ by dihyropyridine calcium channel antagonists strongly suggest that a PXR-independent pathway(s) for gene activation also exists.

In conclusion, we suggest here for the first time that the length of the side chain at the 3-position of the dihydropyridine ring and the position of the nitro group in the nitrophenyl substituent in the structure of Nif, Nis, Nit, Nim, and Nic are important factors determining their ability to activate the $C Y P 2 B 1$ and $C Y P 3 A 1$ genes, respectively.

Acknowledgments This work was supported in part by a Grant-in-Aid for Scientific Research from the Japan Society for the Promotion of Science (M.D.).

\section{REFERENCES}

1) Schlanz K. D., Myre S. A., Bottorff M. B., Clin. Pharmacokinet., 21, 344-356 (1991).

2) Rosenthal T., Ezra D., Drug Safety, 13, 157-187 (1995).

3) Campana C., Regazzi M. B., Buggia I., Molinaro M., Clin. Pharmacokinet., 30, 141-179 (1996).

4) Bertz R. J., Granneman G. R., Clin. Pharmacokinet., 32, 210-258 (1997).

5) Pichard L., Fabre I., Fabre G., Domergue J., Saint A. B., Mourad G., Maurel P., Drug Metab. Dispos., 18, 595-606 (1990).

6) Ma B., Prueksaritanont T., Lin J. H., Drug Metab. Dispos., 28, 125$130(2000)$

7) Zangar R. C., Okita J. R., Kim H., Thomas P. E., Anderson A., Edwards R. J., Springer D. L., Okita R. T., J. Pharmacol. Exp. Ther, 290, 1436-1441 (1999).

8) Konno Y., Nemoto K., Degawa M., Xenobiotica, 33, 119-129 (2003).

9) Konno Y., Sekimoto M., Nemoto K., Degawa M., Toxicol. Appl. Pharmacol., 196, 20-28 (2004).

10) Drocourt L., Pascussi J.-M., Assenat E., Fabre J.-M., Maurel P., Vilarem M.-J., Drug Metab. Dispos., 29, 1325-1331 (2001).

11) Omiecinski C. J., Hassett C., Costa P., Mol. Pharmacol., 38, 462-470 (1990).

12) Oinonen T., Lindros K. O., Biochem. J., 309, 55-61 (1995).

13) Nemoto K., Miyata S., Nemoto F., Yasumoto T., Murai U., Kageyama H., Degawa M., Biochem. Biophys. Res. Commun., 275, 472-476 (2000). 